\title{
Serum Creatinine and Urine Microalbumin Level in Hypertensive and Non hypertensive Patients.
}

\author{
Keshab Raj Joshi', Ashish Gautam², Dipendra Raj Pandeya³, Keshab Poudel'. \\ ${ }^{1}$ Department of Biochemistry, Lumbini Medical College, ${ }^{2}$ Department of Biochemistry, National \\ Technical College, ${ }^{3}$ Department of Biochemistry, Nepal Army Institute of Health Science, ${ }^{4}$ \\ Department of Biochemistry, Apollo Hospital, Delhi.
}

\begin{abstract} hypertensive) group

\section{INTRODUCTION}

Hypertension is defined as systolic pressure $\geq 140 \mathrm{~mm}$ $\mathrm{Hg}$ and or diastolic pressure $\geq 90 \mathrm{~mm} \mathrm{Hg}^{1}$. The kidney is a main target of organ damage in hypertension, and long-term exposure to elevations in blood pressure (BP), even within the normotensive range, can induce early renal damage ${ }^{2}$.
\end{abstract}

Introduction: Hypertension is one of the most common cardiovascular disorders, more likely to accelerate atherosclerosis causing cardiovascular complications and benign arteriolar nephrosclerosis for an extended period of time may manifest as a mild to moderate elevation of serum creatinine and/or microalbuminuria.

Methods: The present study was carried out on total 100 subjects which were divided into two groups. First group of experimental group consisted of 50 subjects with known hypertensive subjects. Another group is control group consisting of 50 non-hypertensive subjects with no present and past family history of hypertension.

Results: The serum creatinine and microalbuminuria were estimated, compared and correlated in hypertensive case group with healthy normotensive group. In case group there was significantly elevated urine microalbumin and serum creatinine levels when compared to controls and also significant positive correlation between serum creatinine and urine microalbumin levels in case group (hypertensive) as compared to control (non

Conclusions: In the present study it has been concluded that in hypertensive patients serum creatinine, urine microalbumin is stastistically elevated in subjects group when compared to the control group.

Keywords: hypertensive patients; serum creatinin; microalbuminuria.

Microalbuminuria defined as excretion of urinary albumin greater than or equal to $4.8 \mu \mathrm{g} / \mathrm{min}$, is a strong independent determinant in hypertension and measurement is recommended for risk stratification in hypertension ${ }^{3,4,5}$. Urinary Albumin Excretion (UAE) in hypertensive patients is a continuous and progressive marker of renal damage and cardiovascular events and also reflects vascular damage, and appears to be a marker of early arterial disease. For this reason, the assessment of urinary albumin excretion is an important aspect for risk factor stratification in hypertensive patients ${ }^{6}$.

There are very few studies which have correlated creatinine and UAE with hypertension in our country. The aim of this study was to compare and correlate serum creatinine and urine microalbumine in hypertensive and normotensive patients.

\section{METHODS}

The present study was carried out on total 100 subjects, which were divided into experimental and control groups. Experimental group consisted of 50 subjects of known hypertensive and control group consisted of 50 subjects who were healthy normotensive subjects with

\section{Correspondence:}

Keshab Raj Joshi

Department of Biochemistry

Lumbini Medical College, Pravas, Tansen, Palpa, Nepal

Email: keshabrajoshi@gmail.com 
no present and past history of hypertension.

Subjects with diabetes mellitus, cardiac patients, alcoholic patients, smokers, renal failure, patient with nephropathy were excluded from the study. Spot urine sample was collected from the subject in container for the estimation of urine microalbumin level and venous blood sample was collected and sample was centrifuged for the estimation of serum creatinine level. The sample was analysed by using biochemistry auto analyzer. Bs-300 chemistry analyzer (Mindray) was used for the analysis of both the urine microalbumin and serum creatinine level.

\section{RESULTS}

The mean age of experimental group was $33.38 \pm 5.33$ in comparison to $33.84 \pm 5.15$ years of control group ( $>0.05)$. Age group distribution was also similar in both the groups. Similarly the gender distribution was also not significantly different in both the groups $(\mathrm{p}=0.689)($ Table 1).

Among the control groups all the subjects had microalbumin levels in urine within normal range $(<30$ $\mathrm{mg} / \mathrm{l}$ ), whereas the levels were above $30 \mathrm{mg} / \mathrm{l}$ in all the subjects of experimental group $(\mathrm{p}<0.001)$.

Table 1: Demographic parameters.
Table 2: Mean levels of urine microalbumin and serum creatinine in two groups

\begin{tabular}{|c|c|c|c|} 
& Controls & Cases & P value \\
\hline $\begin{array}{c}\text { Urine } \\
\text { microalbumin }\end{array}$ & $14.36 \pm 8.78$ & $171.26 \pm 348.93$ & $0.002 * *$ \\
\hline $\begin{array}{c}\text { Serum } \\
\text { creatinine }\end{array}$ & $1.05 \pm 0.14$ & $1.17 \pm 0.25$ & $0.002 * *$ \\
\hline
\end{tabular}

There is a significant increase in mean SBP and DBP in experimental group with mean SBP of $181.00 \pm 39.81$ and DBP of $102.40 \pm 18.41$ compared to $112.56 \pm 4.13$ and $73.60 \pm 4.85$ respectively in control group $(p<0.001)$ (Table 3). The level of blood pressure is in direct correlation with micro albuminuria confirmed by Pearson correlation coefficient $(\mathrm{r}=0.707, \mathrm{p}<0.001)$.

Table 3: Mean Levels of SBP and DBP in two groups of Patients

\begin{tabular}{|l|c|c|c|}
\hline $\begin{array}{c}\text { Blood } \\
\text { Pressure }\end{array}$ & Controls & Cases & P value \\
\hline SBPs & $112.56 \pm 4.13$ & $181.00 \pm 39.81$ & $<0.001$ \\
\hline DBP & $73.60 \pm 4.85$ & $102.40 \pm 18.41$ & $<0.001$ \\
\hline
\end{tabular}

\begin{tabular}{|c|c|c|c|}
\hline Parameters & Control Group & Experimental group & $p$ \\
\hline Mean age & $33.84 \pm 5.15$ & $33.38 \pm 5.33$ & $>0.05$ \\
\hline $\begin{array}{l}25-30 \\
31-40 \\
41-50\end{array}$ & $\begin{array}{l}14(28 \%) \\
29(58 \%) \\
7(14 \%)\end{array}$ & $\begin{array}{l}15(34 \%) \\
27(54 \%) \\
6(12 \%)\end{array}$ & \\
\hline $\begin{array}{r}\text { Male } \\
\text { Female }\end{array}$ & $\begin{array}{l}25(50 \%) \\
25(50 \%)\end{array}$ & $\begin{array}{l}27(54 \%) \\
23(46 \%)\end{array}$ & 0.689 \\
\hline
\end{tabular}

The level of serum creatinine was more in experimental group in comparison to control group, however, the difference was not statistically significant $(\mathrm{p}=0.242)$. Only $6 \%$ of experimental group had creatinine levels above normal range $(<1.4 \mathrm{mg} / \mathrm{dl})$ whereas all subjects $(100 \%)$ of control group had serum creatinine level in normal range.

The mean urine micro albumin (171.26 \pm 348.93$)$ and serum creatinine $(1.17 \pm 0.25)$ were significantly increased in experimental group when compared to mean micro albumin $(14.36 \pm 8.78)$ and creatinine $(1.05 \pm 0.14)$ of control group $(\mathrm{p}=0.002)$ (Table 2$)$.

\section{DISCUSSION}

Hypertension is a major public health problem in India and in other developing countries. Hypertension affects approximately $25 \%$ of the adult population worldwide and its prevalence is predicted to increase by $60 \%$ by 2025 A.D ${ }^{8}$.

High blood pressure is an important independent predictor of the development and progression of chronic renal disease as well as morbidity and mortality in patients with chronic renal disease ${ }^{9}$.

Blood pressure and creatinine level are associated in 
the general population. The observed association is stronger when a number of years had elapsed between the assessments of blood pressure and creatinine level. These finding are consistent with the hypothesis that blood pressure elevation, even below the hypertensive range, may induce early renal damage ${ }^{10}$.

The study of Kadiri showed that the serum creatinine was higher in hypertensive than in normotensive but the differences were not statistically significant. Adjusted creatinine clearance was significantly lower in hypertensive than normotensive (both in male and female) $)^{11}$.

In the present study serum creatinine level were suggestive significance and was high normal in hypertensive patients compared to non hypertensive patients which is a match with previous studies ${ }^{12,13}$.

In our study levels of urine microalbumin were significantly high in hypertensive patients compared to non hypertensive patients which is also similar to previous studies $^{14,15}$.

\section{CONCLUSION}

Urine microalbumin in two studied groups, were significantly increased and a positive correlation was observed between serum creatinine levels and urine microalbumin $(\mathrm{r}=0.707, \mathrm{p}<0.001)$ in case group as compared to control group.

\section{REFERENCES}

1. Whitworth JA, Chalmers J." World health organization-international society of hypertension (WHO/ISH) hypertension guidelines",Oct-Nov 2004:26(7-8):747-752.

2. Perneger TV, Nieto FJ, Whelton PK, Klag MJ,et. al." A prospective study of blood pressure and serum creatinine: results for the "Clue" Study and the ARIC Study". JAMA. 1993; 269: 488493. http://dx.doi.org/10.1001/jama.269.4.488 h PMid:8419668

3. Klaus Peder Klausen, Henrik Scharling, Gorm Jensen and Jan Skov Jensen." New Defination of Microalbuminuria in Hypertensive subjects: Association with incident coronary heart disease and death"American heart association, 2005;46:33-37.

4. Asterios karagiannis, Dimitri P. Mikhailidis, Konstantinos Tziomalos, Anna I. Kakafika, et.al. Editorial- "As the time come for a new definition of microalbuminuria"? Current Vascular Pharmacology, 2008; 6(2): 81. http:// dx.doi.org/10.2174/157016108783955329 PMid:18393908

5. Giuseppe Schillaboci, MD, Gianpaolo Reboldi, MD and Paolo Verdecchia, MD." High-Normal Serum Creatinine Concentration Is a Predictor of Cardiovascular Risk in Essential Hypertension", Arch Intern Med. 2001; 161: 886-891.http:// dx.doi.org/10.1001/archinte.161.6.886

6. Fernando De Alvaro, Olga Veoasco, Jesus Hanorato, Carlos calvo, et.al. "Microalbuminuria in hypertensive patients: Evaluation of One year study treatment with irbesartan", Kideny international, 2005; 67(93): S29-S34.

7. Thomas V. Pernege, F. javier Nieto, Paul K. Whelton, Michael J. Klag, et al. "A prospective study of blood pressure and serum creatinine" JAMA, January 27, 1993; 269(4). PMid:8501841

8. Kearney PM, Whelton M, et al. "Global burden of hypertension: analysis of world wide data" Lancet, 2005; 365: 217-223.http://dx.doi.org/10.1016/ S0140-6736(05)17741-1

9. Whelton PK, Klag MJ. "Hypertension as a risk factor for renal disease: review of clinical and epidemiological evidence" Hypertension, 1989; 13: 119-127. http://dx.doi.org/10.1161/01. HYP.13.5_Suppl.I19

10. Thomas V. Pernege, F.javier Nieto et al. "A prospective study of blood pressure and serum creatinine" JAMA, January 27, 1993; 269(4). PMid:8501841

11. Sarkar D, Latif SA, et al. "Studies on Serum Creatinine and Creatinine Clearance in Hypertensive Patients" J Bangladesh Soc Physiol, Dec 2006; (1):19-26.

12. Giuseppe Schillaboci, MD, Gianpaolo Reboldi, et al "High-Normal Serum Creatinine Concentration Is a Predictor of Cardiovascular Risk in Essential Hypertension", Arch Intern Med, 2001; 161: 886891. http://dx.doi.org/10.1001/archinte.161.6.886 
13. S. Goya Wannamethee, A. Gerald Shaper et al. "Serum Creatinine concentration and risk of cardiovascular disease", American Heart Association, Inc; stroke, 1997; 28: 557-563.

14. John P Forman, Naomi D.L. Fisher et al. "Higher levels of Albuminuria within the normal range predict incident hypertension." J Am Soc Nephrol, 2008; 19:1983-1988. http://dx.doi. org/10.1681/ASN.2008010038 PMid:18579639 PMCid:PMC2551568

15. Kathleen D. Pagana, RN. "Microalbumin: Little test, big payoff" American Nurse Today, October 2006. 